\title{
Differentiation of stem and progenitor cells from bone marrow in activated dendritic cells and lymphocytes with anti-malignant properties
}

\author{
Iskra Ventseslavova Sainova*, llina Valkova, Velichka Pavlova and Elena Nikolova \\ Institute of Experimental Morphology, Pathology and Anthropology with Museum-Bulgarian Academy of Sciences, \\ 1113 Sofia, Bulgaria. \\ Accepted 24 April, 2013
}

\begin{abstract}
Dendritic cells (DCs) have been characterized as powerful antigen-presenting cells (APCs), which possess the abilities for immune modulation and are used in composition of anti-malignant vaccines and gene-engineered products. By appropriate cultivation, modifications of DCs have shown abilities for an enhanced expression of specific effector molecules. Studies on their biology are focused on their role as main immune response modulators. These properties characterize them as promising candidates for construction of novel safe vaccines and gene-engineered products. In this direction, attention is directed to development of methods and techniques for transduction of in vitro- and/or ex vivo-cultivated DCs with previously designed recombinant viral vectors with inserted genes, coding respective malignant antigens. Studies on the biology of lymphocytes are mainly focused on their role in cellular and humoral immune response. Their cultivation and differentiation in the presence of appropriate antigens, on one hand, and by appropriate modifications, on the other hand, have shown the abilities for an enhanced expression of specific effective molecules. These properties have characterized them as promising candidates for construction of novel safe vaccines and geneengineering products.
\end{abstract}

Key words: Stem/progenitor cells, dendritic cells, lymphocytes, cell differentiation, recombinant viral vectors/gene constructs, malignant disorders, immunity.

\section{INTRODUCTION}

Dendritic cells (DCs) have been found to play a pivotal role in initiating the immune response, including powerful antigen-presenting cells (APCs) (Arthur et al., 1997; Avigan, 2004; Bonini et al., 2001; Bubenik, 2001; Caux et al., 1992; Clark et al., 1992; Gong et al., 1997; Hassan et al., 2000; Inaba et al., 1992; Kaplan et al., 1999; Kim et al., 1994; Reid et al., 1992; Ribas et al., 1997; Siena et al., 1995; Yongqing et al., 2002). In the light of their unique properties, these cells have been proposed as powerful immunomodulation agents, including in the composition of novel vaccines and gene-engineering products for treatment of malignant disorders.
Primitive hematopoietic stem cells (HSCs) have been found to be hierarchically ordered on the basis of quiescence, the most primitive of these, characterized by their $\mathrm{Rh} / \mathrm{Ho}$ (dull) phenotype and their capacity for long-term hematopoietic reconstitution, are not dormant, but they have been established to cycle slowly in normal steadystate bone marrow (Ballas et al., 2002; Bradford et al., 1997; Bradley et al., 2002; Cheng et al, 1998; Gunechea et al., 2000; Koido et al., 2007; Lai and Kondo, 2007; Le Blannk and Ringden, 2005). Unrelated human MSCs have not been found to elicit T-cell activation in vitro and to suppress T-cell activation by tuberculin and unrelated 
allogeneic lymphocytes in a dose-dependent manner. It has been reported that the Lin-IL-7R+Thy-1-Sca-1locKit(lo) population from adult mouse bone marrow possess a rapid lymphoid-restricted (T-, B-lymphocytes, as well as natural killer (NK) cells) reconstitution capacity in vivo, but completely lacked myeloid differentiation potential both in vivo and/or in vitro (Bovia et al., 2003; Kobari et al., 2001). A single Lin-IL-7R+Thy-1-Sca-1loc$\mathrm{Kit}(\mathrm{lo})$ cell has been established to be able to generate at least both T- and B-cells (Amirayan et al., 1995; Bovia et al., 2003; Bregenholt et al., 1996; Dallas et al., 2007; Gray-Parkin et al., 2002; Green et al., 1992; Ikuta et al., 1990; Jackson and Bell, 1990; Kondo et al., 1997). These data have provided direct evidence for the existence of common lymphoid progenitors in sites of early hematopoiesis. Interferons (IFNs) and protein-kinases (PKRs) have demonstrated abilities to sensitize cells to apoptosis predominantly through the FADD/caspase- 8 pathway.

Complex mechanisms, which include molecular, genetic and cellular components, such as Wnt-, BMPand Notch/Delta-signaling pathways, have been found to underlie differentiation and functions of stem cells (Caux et al., 1992; Ribas et al., 1997; Terskikh et al., 2006; Vogelstein and Kinzler, 2004). By use of real time polymerase chain reaction (RT-PCR), an ability for initiation of erythroid ( $\beta$-globin) and/or myeloid (myeloperoxidase) gene expression programs by the same cell prior to exclusive commitment to the erythroid, myeloid lineages for it has been shown (Bonini et al., 2001; Caux et al., 1992; Curti et al., 2001; Davis et al., 1996; Inaba et al., 1992; Reid et al., 1992; Siena et al., 1995).

These data have supported a model of hematopoietic lineage specification, in which unilineage commitment has been prefaced by a "promiscuous" phase of multilineage locus activation (Bonini et al., 2001; Curti et al., 2001; Engelmayer et al., 2001; Reid et al., 1992; Siena et al., 1995). Protein BCL-6 has also been detectable in inter- and intra-follicular CD4+ T-cells, but not in other follicular components, including B-cells, plasma cells, monocytes/macrophages and DCs. Genes potentially important in myeloid differentiation, such as coding granulocyte colony-stimulating factor (G-CSF) and the enzyme myeloperoxidase, have been found to be located close to the breakpoint in the $t(15 ; 17)$, but have not been conclusively shown to be rearranged in this chromosomal translocation (Bonini et al., 2001; Engelmayer et al., 2001; Reid et al., 1992; Siena et al., 1995).

It has also been proposed that the commitment of common myeloid progenitors to either the megakaryocyte /erythrocyte or the granulocyte/ macrophage lineages are mutually exclusive events (Bonini et al., 2001; Caux et al., 1992; Curti et al., 2001; Hassan et al., 2000; Reid et al., 1992; Siena et al., 1995). It has been concluded that active cell cycling of bone marrow cells, induced by cytokine stimulation, is probably very often associated with an engraftment defect in the normal host, and derangement of these pathways within stem cells, as well as the apparent lineage and differentiation status, have been found to play an important role in the development of malignancies.

In agreement with representing a lymphoid primed progenitor, Lin-Sca-1+c-kit+CD34+Flt3+ cells have been established to display up-regulated IL-7 receptor gene expression (Amirayan et al., 1995; Bregenholt et al., 1996; Dallas et al., 2007; Gray-Parkin et al., 2002; Green et al., 1992; Ikuta et al., 1990; Jackson and Bell, 1990; Kondo et al., 1997). Based on these observations, a revised road map for adult blood lineage development has been proposed. Protein Klotho has been indicated to be able to regulate B-lymphopoiesis via its influence on the hematopoietic microenvironment. SUMO-2 and SUMO-3 have been found as localized to chromosome earlier and accumulated gradually during telophase. These findings have demonstrated that mammalian SUMO-1 shows patterns of utilization that are clearly discrete from the patterns of SUMO-2 and SUMO-3 throughout the cell cycle, arguing that it is functionally distinct and specifically regulated in vivo, and on the other hand, that myeloid progenitor number and developmental potential do not decline with age indicates that B-lymphopoiesis is particularly sensitive to defects that accumulate during senescence (Amirayan et al., 1995; Bregenholt et al., 1996; Dallas et al., 2007; GrayParkin et al., 2002; Green et al., 1992; Ikuta et al., 1990; Jackson and Bell, 1990; Kondo et al., 1997; Kobari et al., 2000; Lazarus et al., 2005). Diseases and disorders, connected with retardations in these processes, have been defined as clone HSCs malignancies, characterized by independency and/or hypersensitivity of HSCs and/or of haematopoietic precursors to numerous cytokines. In many patients with such diseases, a mutation in such gene has been established, and its presence in erythropoietin-independent erythroid colonies have demonstrated a link with growth factor hypersensitivity, which has been characterized as a key biologic feature of these disorders (Sell, 2004).

Mesenchymal stem cells (MSCs) have been indentified in bone marrow as well as in other tissues of the joint, including adipose, synovium, periosteum, perichondrium, and cartilage, as well as to modulate immune responses, exhibit healing capacities, improve angiogenesis and prevent fibrosis (Djouad et al., 2009; Maitra et al., 2004; Terskikh et al., 2006). These properties have characterized these cells as usable for therapeutic applications in many different diseases and disorders. MSCs have also proved abilities to support tissue repair, angiogenesis and concomitant immunomodulation and to provide tissue-specific functional biodiversity, additionally mediated by direct cell-cell communications via adhesion molecule and by exchange of cytokines, exosomes and micro-RNAs (Hass and Otte, 2012; Maitra et al., 2004; Terskikh et al., 2006 Maitra et al., 2004; Terskikh et al., 2006). These features allow MSCs be used for treatment 
of various morbid and degenerative processes (Kang et al., 2012; Ra et al., 2011).

\section{BIOLOGICAL PROPERTIES OF DENDRITIC CELLS AND THEIR ROLE IN GENERATION OF ADEQUATE IMMUNE RESPONSE}

In the past years, the development of novel therapeutic strategies with DCs has become extensively investigated (Arthur et al., 1997; Bonini et al., 2001; Bubenik 2001; Caux et al., 1992; Clark et al., 1992; Gong et al., 1997; Hassan et al., 2000; Inaba et al., 1992; Kaplan et al., 1999; Kim et al., 1994; Reid et al., 1992; Ribas et al., 1997; Siena et al., 1995; Wang et al., 1995). According to many literature data, granulocyte-macrophage colonystimulating factor (GM-CSF) mobilizes CD34+ bone marrow progenitor cells both in vitro and in vivo with an increased frequency and generation of DCs with antimalignant properties (Banchereau et al., 2000; Caux et al., 1992; Curti et al., 2001; Inaba et al., 1992; Lehtonen et al., 2007; Reid et al., 1992; Siena et al., 1995). In DCs, but not in macrophages, basal expression of SOCS-1 has been detected (Figure 1) (Lehtonen et al., 2007).

Specific protein inhibitors from the SOCS family have been proven as modulators of the activated DCs by IL-4 and GM-CSF cytokine signaling via the JAK/STAT pathway. Similarly, the addition of GM-CSF plus tumor necrosis factor- $\alpha$ (TNF- $\alpha$ ), has been found to induce development of DCs from purified CD34+ cells of bone marrow, cord blood and peripheral blood (Caux et al., 1992; Reid et al., 1992; Siena et al., 1995). The critical role of TNF- $\alpha$ for the differentiation of DCs has been supported by the demonstration that this cytokine induces the expression of molecule CD40 on CD34+ cells (Curti et al., 2001; Reid et al., 1992; Siena et al., 1995). Besides that, CD34+/CD40+ cells have been found to express only myeloid markers, significantly increase alloantigen presenting function, compared with total CD34+ cells, and have also given rise to high numbers of DCs. Modulation of DCs differentiation from these bipotent CD34+/CD40+ cells during the later stages of their cultivation, has also been shown by cytokine interleukin-4 (IL-4). On the other hand, appropriate modifications of DCs to express tumor-antigens by in vitro and/or ex vivo-transfer of genes, coding respective antibodies, has been suggested. Taken together, these data have revealed abilities for development of different therapeutic strategies of DCs for immunotherapy of malignant diseases.

\section{DEVELOPMENT OF NOVEL THERAPEUTIC STRATEGIES WITH DENDRITIC CELLS}

The antigen-presenting functions of DCs, could theoretically be exploited as a new therapeutic tool in cancer therapy in order to amplify immune responses against tumor-specific antigens (Arthur et al., 1997; Avigan, 2004; Bennett et al., 2001; Bonini et al., 2001; Bubenik, 2001; Caux et al., 1992; Clark et al., 1992; Gong et al., 1997; Hassan et al., 2000; Inaba et al., 1992; Kaplan et al., 1999; Kim et al., 1994; Reid et al., 1992; Ribas et al., 1997; Siena et al., 1995). Promising results from clinical trials in patients with malignant lymphoma, melanoma and prostate cancer, have suggested that immunotherapeutic strategies that take advantage of the antigen presenting properties of DCs, might ultimately prove both efficacious and widely applicable against human malignancies (Fong and Engelman, 2000). Besides that, genetically-modified cells have been widely tested in preclinical studies, including anti-malignant agents (Arthur et al., 1997; Avigan, 2004; Bennett et al., 2001; Bonini et al., 2001; Borysievicz et al., 1996; Engelmayer et al., 2001; Eo et al., 2001; Frasca et al., 2006; Gong et al., 1997; Kaplan et al., 1999; Panicali and Paoletti, 1982; Reid et al., 1992; Ribas et al., 1997; Siena et al., 1995; Wang et al., 1995; Wildner and Morris, 2000; Yongqing et al., 2002).

\section{DEVELOPMENT OF NOVEL THERAPEUTIC STRATEGIES WITH HYBRID CELLS, PREPARED BY FUSION OF DENDRITIC AND MALIGNANT CELLS}

As alternative method for delivery into DCs, their fusion with tumor cells has been utilized, as well as the hybrid cell-based vaccines have shown high therapeutic activity, even in patients with malignant diseases (Avigan, 2004; Gong et al., 2000; Hiraoka et al., 2004; Walden, 2000; Yongqing et al., 2002). Induced by vaccination with dendritic/tumor fusion cells, antitumor immunity has reacted differently to injected malignant cells and autochthonous malignancies (Xia et al., 2003). It has also been shown that immunization with such fusion cells induces rejection of established metastases (Gong et al., 1997). The observed greatly reduced number of established pulmonary metastases both with and without in vivo-administration of IL-2 adoptive transfer of T-cells derived from B16/DC vaccine-primed lymph nodes into B16 tumor-bearing mice has suggested a role for the cells, developed by fusion of malignant cells with DCs hybrid products, as effective cellular vaccines for eliciting T-cell-mediated anti-malignant immunity (Wang et al., 1998). Hybrid cells, developed by fusion between DCs and tumor cells, have been found to express both major histocompatibility complex (MHC) class I- and class IIrestricted tumor-associated epitopes and might, therefore, be useful for the induction of tumor-reactive CD8+ and CD4+ T-lymphocytes both in vitro and in human vaccination trials (Parkhurst et al., 2003). It has also been demonstrated that immunization with such vaccines, developed by fusion of DCs with mouse 4TOO plasmacytoma cells FC/4TOO hybrid fusion cells plus IL 12 potentiates anti-malignant immunity and the treatment of murine multiple myeloma (Gong et al., 2000; 2002). 
Findings about fusions of ovarian cancer cells to autologous or allogeneic DC induced cytolytic T-cell activity and lysis of autologous malignant cells by a MHC class I-restricted mechanism, have suggested that fusions of such malignant cells and DCs activate T-cell responses against autologous malignancies, and the fusions are probably functional, when they are generated with either autologous or allogeneic DCs. It has also been demonstrated that sequential stimulation with hybrid cells, derived by fusion of DCs with breast carcinoma fusion cells and anti-CD3/CD28, results in a marked expansion of activated tumor-specific T-lymphocytes, which has suggested these fusion cells are probably effective antigen-presenting cells (APCs), which stimulate inhibitory T-cells that limit vaccine efficacy (Vasiri et al., 2008). On the other hand, the results, according to which the ex vivo-exposure of DCs to TGF- $\beta$ has not appeared to lessen the efficacy of DCs vaccines, suggest that tumor-derived TGF- $\beta$ probably reduces the efficacy of $\mathrm{DC} /$ malignant cell hybrid fusion vaccine via an in vivomechanism, and the neutralization produced by the fusion cells TGF- $\beta$ might enhance the effectiveness of DCs-based immunotherapy (Kao et al., 2003). The immunogenicity of a DCs/malignant cells fusion hybrid cells-based vaccines has been increased by heat-treated tumor cells (Koido et al., 2007).

\section{DEVELOPMENT OF NOVEL THERAPEUTIC STRATEGIES WITH CELLS BY INSERTION OF ADDITIONAL CYTOKINE GENES AND ANTIGENS BY TRANSFECTION WITH RECOMBINANT GENE CONSTRUCTS}

It has been demonstrated that initial materials for geneengineering manipulations could be used by both DNAand RNA-viruses, as well as bacterial plasmids and yeast's genomes (Arthur et al., 1997; Avigan, 2004; Bennett et al., 2001; Bonini et al., 2001; Borysievicz et al., 1996; Bubenik, 2001; Chen et al., 1997; Chun et al., 1999; Domi and Moss, 1995; Engelmayer et al., 2001; Eo et al., 2001; Frasca et al., 2006; Gambotto et al., 1999; Gong et al., 1997; Guenechea et al., 2000; Hass et al., 2000; Kaplan et al., 1999; Kauffman et al., 2001; Martinet et al., 1997; Palese and Roizman, 1996; Panicali and Paoletti, 1982; Reid et al., 1992; Ribas et al., 1997; Siena et al., 1995; Wang et al., 1995; Wildner and Morris, 2000; Yongqing et al., 2002). This indicates eventual existence of a possibility for insertion of genes, coding cell receptors, cytokines, enzymes, complement components, apoptosis activators and/or inhibitors, surface antigens, as well as markers for malignancy. Many studies have suggested that hybrid viral vector systems could improve the suicide gene therapy of tumors. These results would have significant implications for the improvement of clinical gene therapy in HIV/AIDS and malignantdiseases. Inasimilarway, theobservedelimination of the protective effect in depletion of CD8+ Tlymphocytes, but not of CD4+ T-cells in vivo from animals, vaccinated with vaccines, developed on the basis of adenoviral genome recombinant gene construct Ad2CMV-gp100 mice, containing gene for glycoprotein (gp) from cytomegalovirus (CMV) genome, has suggested that these virus recombinants, encoding tumor antigens, could probably be useful as vaccines to induce specific T-cell immunity for therapy of malignant diseases.

\section{DEVELOPMENT OF NOVEL THERAPEUTIC STRATEGIES WITH DENDRITIC CELLS, CONTAINING ADDITIONAL CYTOKINE GENES AND ANTIGENS BY TRANSFECTION WITH RECOMBINANT GENE CONSTRUCTS}

In investigation on the role of intra-tumor treatmet on the survival of tumor-bearing experimental animals with herpes-simplex virus (HSV), expression of IL-4 has been found to prolong their survival, whereas expression of IL10 to reduce it (Bennett et al., 2001; Hassan et al., 2000; Liu et al., 2005; Panicali and Paoletti, 1982; Wildner and Morris, 2000). These finding have suggested further investigation on the improvement in the combination of oncolytic viral therapy and immunomodulatory strategies. They have also supported the full use of recombinant adenovirus-transduced DCs for in vivo-immunization against tumor-associated antigens. In laboratory conditions, human DCs, transduced with recombinant virus gene construct $A d V / I L-10$, have been shown to inhibit mixed leukocyte culture, reduced cell surface expression of co-stimulatory molecules CD80/CD86, as well as exhibited inability for production of the potent allostimulatory cytokine IL-12 (Coates et al., 2001). In investigation on the in vivo-properties of the so modified DCs, skin transplantation of humanized immunodeficient non-obese diabetic/severe combined immunodeficient (NOD/SCID) mice, engrafted with human skin, reconstituted via intra-peritoneal injection with allogeneic mononuclear cells (MNCs) mixed with $1 \times 10^{6}$ autologous to the skin donor DCs, transduced with either recombinant virus gene construct $A d V / I L-10$ or of recombinant viral vector $A d V / M X-17$, a reduced skin graft rejection, characterized by reduced infiltration with mononuclear cells and less dermo-epidermal junction destruction in comparison with the animals with inoculation of DCs, modified with the control virus alone, has been observed. Transduced by appropriate adenoviral gene constructs, immature DCs have shown the abilities to differentiate in different directions in respective appropriate conditions of cultivation (Addison et al., 1995; Chen et al., 1997; Dietz and Vuk-Pavlović, 1998; Gambotto et al., 1999; Lu et al., 1998). For example, in the presence of monocyte-conditioned medium, they have indicated ability to express the surface markers 
of mature DCs, such as CD25, CD83, high levels of molecules CD86 and HLA-DR, or to secrete of IL-12. Their ability to induce T-cell growth has also been enhanced. Similarly, in transfer of bacterial gene lacZ, coding the enzyme beta-galactosidase by recombinant retrovirus gene constructs in human DCs, increased expression levels of MHC class I and II molecules, as well as of CD1a, CD80, CD86, CD13, CD33, CD40 and CD54 has been demonstrated (Aicher et al., 1997). So modified DCs have also shown high stimulatory activity in both allogeneic and autologous mixed lymphocyte reaction (MLR). These data have also supported the efficiency of the recombinant viral vectors in studies on the biology of DCs, including the expression of specific antigens for active immune therapy (Aicher et al., 1997; Dietz and Vuk-Pavlović, 1998; Lu et al., 1998).

\section{COMBINED THERAPEUTIC STRATEGIES WITH DENDRITIC CELLS}

For further increase of the potency of the vaccine, a combined variation of both technologies has been applied, in which interleukin-18-transfected DCs have been used to prepare dendritic cells-tumor cells conjugates (Wen et al., 2001). Immunization with such conjugates has significantly increased the production of Th1 cytokine-producing cells, the number of antigen-specific CD8+ T-cells, as well as the anti-malignant immunity.

However, the fact that an increased Th1 cytokine production and stronger anti-malignant effect have not been observed in mice, depleted of IFN- $y$, has also supported the maintenance of DCs/malignant cells conjugates as potent anti-malignant vaccines, and interleukin- 18 could be additionally administered by gene transfection of cells for enhancement of this immunity, which is probably mediated mainly by IFN-Y. Immunization with gene-modified hybrid products, derived by fusion of DCs with malignant cells, received by their fusion with $I L-12$ gene-transferred cancer cells, has shown an ability to elicit a previously enhanced antimalignant effect in experimental therapeutic models in vivo (Suzuki et al., 2005). It has also been indicated that a hybrid vaccine, based on GM-CSF gene-modified DCs, might be an attractive strategy for anti-malignant immunotherapy with potentially increased therapeutic efficacy (Cao et al., 1999). Immunization of mice with engineered DCRMAT/J558-IL-4 hybrids in vitro has elicited stronger J558 tumor-specific CTLs responses and has also induced more efficient protective immunity against J558 tumor challenge, and respectively, in vivo in comparison of hybrid vaccines DCRMAT/J558 (Liu, 2003). Similar results have been observed in immunization of $\mathrm{C} 57 \mathrm{BL} / 6$ mice with gene-engineered

$D C / J 558-$ IL-4 hybrids (Xia et al., 2005). It has also been demonstrated that gene-engineered fusion hybrid vaccines, could be an attractive strategy for cancer immunotherapy. These results have indicated that gene- engineered fusion hybrid vaccines, combined with genemodified tumor and DCs vaccines, as well as their combination with Th1 gene-modified tumor with DCs, might be attractive strategies for cancer immunotherapy (Liu, 2003; Xia et al., 2004).

\section{DEVELOPMENT OF NOVEL THERAPEUTIC STRATEGIES BY LYMPHOCYTE ELIMINATION AND DIFFERENTIATION THERAPY}

By understanding molecular basis, gene expression mechanisms and signaling pathways, which are involved in development and differentiation of HSCs, development of differentiation therapy and elimination therapy strategies have been developed (Cheung et al., 2003). A mutation in one or more genes, which are included in any of the mentioned cascade mechanisms, could be characterized as a probable key biologic feature of these disorders. The most common example is transplantation of allogenic HSCs with graft versus leukemia effect (Figures 1 and 2) (Amirayan et al., 1995; Bregenholt et al., 1996; Cheung et al., 2003; Dallas et al., 2007; Glymcher and Murphy, 2000; Gray-Parkin et al., 2002; Green et al., 1992; Ikuta et al., 1990; Jackson and Bell, 1990; Kondo et al., 1997).

\section{DEVELOPMENT OF NOVEL THERAPEUTIC STRATEGIES BY LYMPHOCYTE DIFFERENTIATION ON THE INFLUENCE OF RECOMBINANT VACCINES, CARRYING SPECIFIC ANTIGENS}

Vaccination strategies with recombinant poliovirus vectors have induced protective immunity against challenge with lethal doses of ovalbumin-expressing malignant melanoma cell line (Mandl et al., 1998). Similarly, novel mechanisms, by which vaccinia virus has been found to interfere with the onset of host immune responses by blocking the interferon-gamma (IFN- $\mathrm{Y}^{-}$) signal cascade mechanism through the dephosphorylating activity of the viral phosphatase $\mathrm{VH} 1$, have been revealed. Tumor infiltrating lymphocytes isolated from metastatic melanoma patients have been characterized as predominantly cytotoxic T-lymphocytes (CTLs) with an ability to recognize and kill autologous tumor cells after their in vitro-cultivation (Borysiewicz et al., 1996; Hodge et al., 1997; Overwijk et al., 1999; Tsang et al., 1995). In mice, inoculated with $I L-15$-expressing vaccinia virus in addition to an increase in NK cells in the spleen, enhanced expression of interleukin-12 (IL-12) and IFN-y, as well as induction of cytokines, has been established. In this way, a possibility for cytokine influence on the response mediated by human HSV therapy, has been suggested, which could probably be due to the host immune response (Andreansky et al., 1998; Liu et al., 2005). Thus, cytokine expression might be an important adjunct to tumor therapy utilizing genetically engineered 


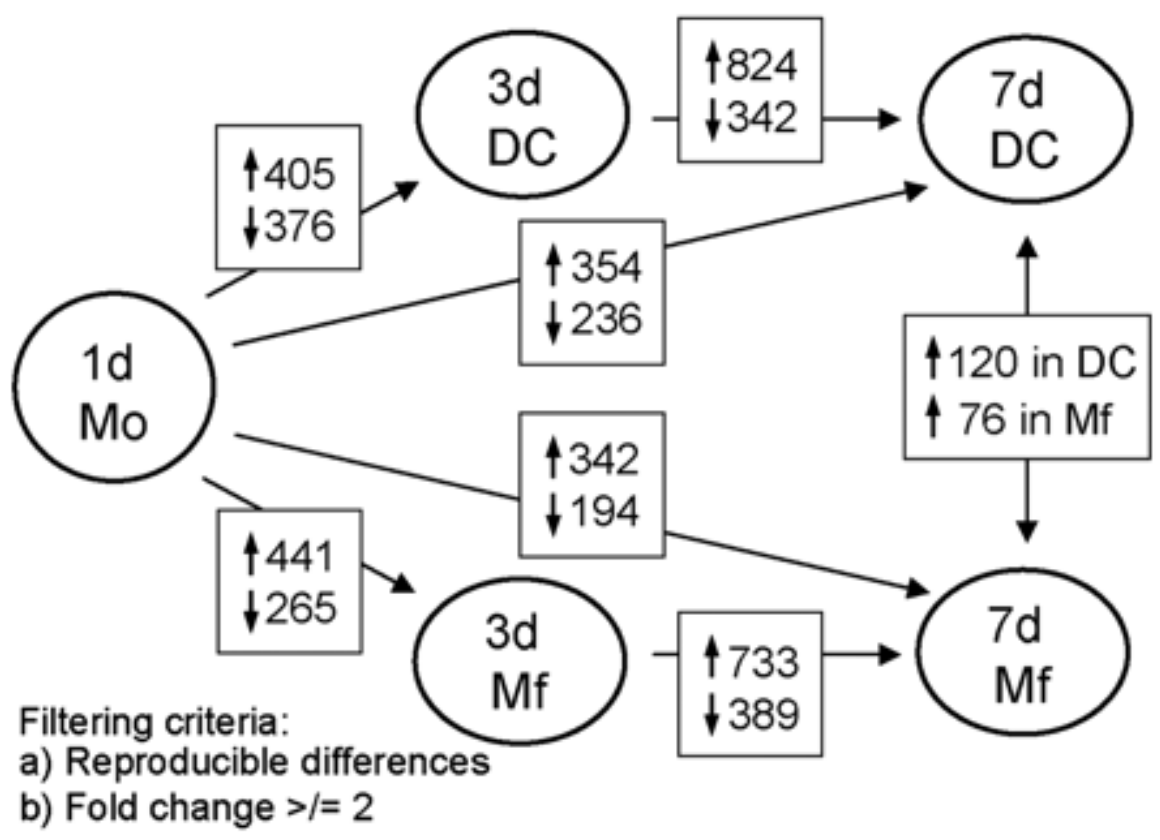

Figure 1. Experimental set-up and numbers of regulated genes during macrophage and DC differentiation (Lehtonen et al., 2007).

HSV. However, in this experimental model system, the degree of attenuation in viral virulence, attained with coexpression of $\mathrm{IL}-15$, has been much less than that, achieved with co-expression of IL-2, which has suggested that the response, mediated by peripheral NK cells, is probably stronger to IL-2 than to IL-15. Immunohistochemical analyses of mouse brains after viral inoculation have shown marked accumulation of inflammatory cells, composed primarily of monocytes/macrophages/ microglia, with various proportions of CD8+ and CD4+ Tcells (Figures 2 and 3) (Glymcher and Murphy, 2000), as well as few B-lymphocytes (Andreansky et al., 1998). These results have also implied that virus-encoded inhibitors of apoptosis, such as the caspase-8 inhibitor CrmA, could block the IFN-mediated apoptosis, and therefore, they are probably able to constitute an alternative family of inhibitors of IFNs in the cell.

In CEA-transgenic mouse model of anti-tumor effects in terms of survival, CD8+ and CD4+ responses, specific for carcino-embryonic antigen (CEA), have been observed (Figures 2 and 3) (Glymcher and Murphy, 2000; Tsang et al., 1995). The utilization of a diversified immunization scheme, using a recombinant vaccinia virus, followed by recombinant avian pox virus, has been shown to be far superior to the use of either one alone in eliciting CEAspecific T-cell responses (Hodge et al., 1997). These studies have demonstrated that the use of cytokines and diversified prime and boost regimens could be combined with the use of recombinant viral vectors, expressing multiple co-stimulatory molecules to further amplify T-cell responses. IL-2 has also been found to induce their proliferation and to augment their cytotoxic activity such that they eliminated autologous malignant cells.

The addition of GM-CSF to $r F-C E A$ or $r F-C E A / T R I C O M$ vaccinations via the simultaneous administration of recombinant viral vector $r F-G M-C S F$ has enhanced CEAspecific T-cell response (Sadegah et al., 2000). Because protein $\mathrm{Bcl}-3$ has been characterized as a member of inhibitors from the subfamily the Nuclear Factor-kappaB (NFKB), a regulation mechanism on the apoptosis and survival of activated T-cells, supported by the balance in the concentration of various members of this family, has been suggested (Glymcher and Murphy, 2000; Mitchell et al., 2001). It has also been proposed that the deliberate induction of self-reactivity by use of a recombinant viral vector, could lead to tumor destruction, but CD4+ Tlymphocytes (Figure 3 ) are probably an integral part of this process, and hence, targeting tissue differentiation antigens vaccine strategies might be valuable in malignancies, arising from non-essential cells, tissues and organs, such as melanocytes, prostate, testis, breast and ovary (Aruga et al., 1997; Glymcher and Murphy, 2000; Grosenbach et al., 2001; Itoh et al., 1995; 1986; Kent et al., 1998; Rosenberg, 1996; Rosenberg et al., 1994; Siders et al., 1998; Wang et al., 1995; Zhai et al., 1996). Treatment of patients with metastatic melanoma with tumor-infiltrating lymphocytes (TILs) and IL-2 has resulted in objective immune responses in them.

Studies on the specific T-cell responses via stimulation of peripheral blood lymphocytes with specific peptide epitopes from the CEA have demonstrated clear differences in establishment of T-cell lines post-immunization. These lines have been CD8+ and/or CD4+/CD8+, to lyse cells, transformed by Epstein-Barr virus (EBV) B- 


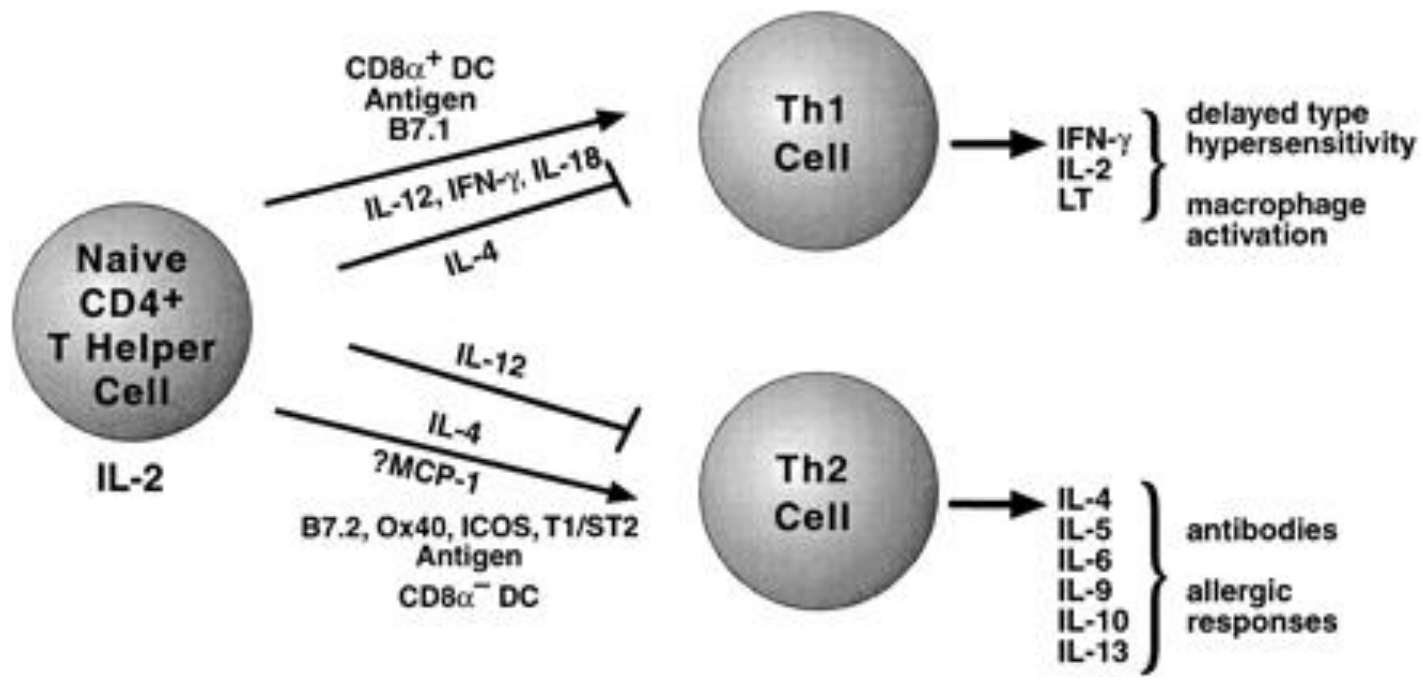

Figure 2. Signals, influencing differentiation of T-helper lymphocytes (Glymcher and Murphy, 2000).

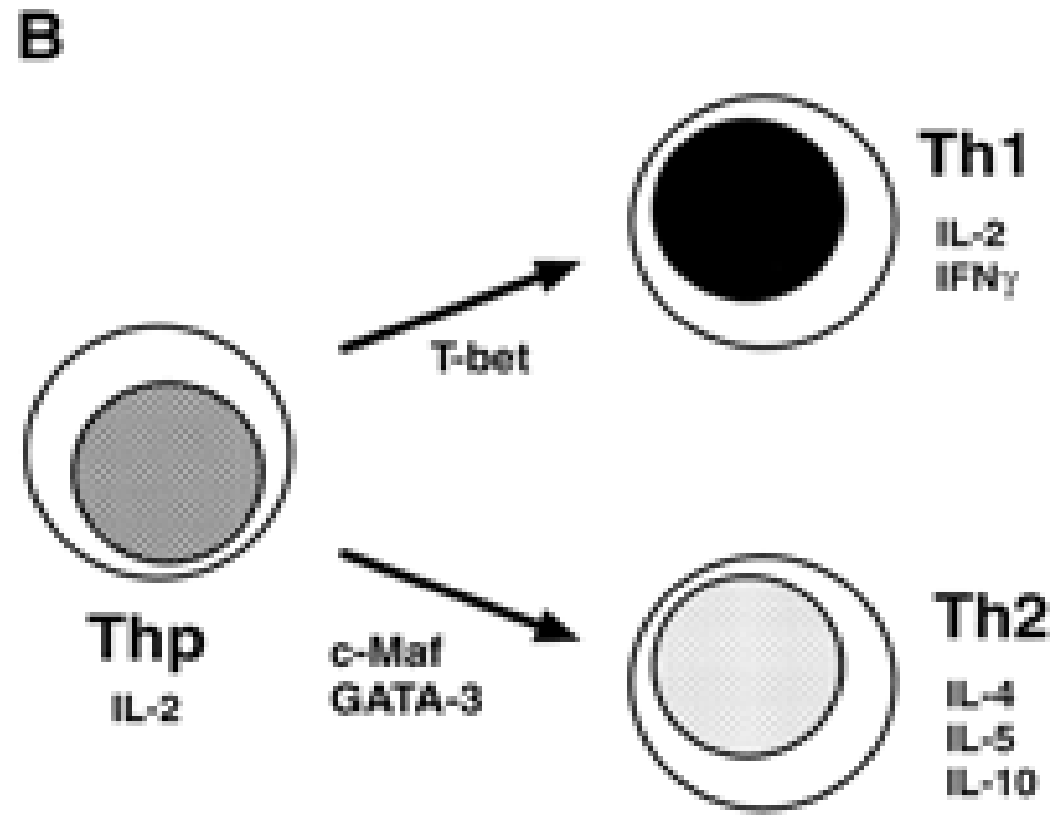

Figure 3. Transcription factors, influencing differentiation of T-helper lymphocytes $(A)$; Tissue-specific factors that regulate $\mathrm{CD}^{+}{ }^{+}$T-helper cell differentiation (B) (Glymcher and Murphy, 2000).

lymphocytes and transduced with gene CEA, and to lyse CEA-positive carcinoma cells in a human leukocyte antigens (HLA) restricted manner (Hodge et al., 1997; Sadegah et al., 2000; Tsang et al., 1995). It has also been suggested as a model ofmetastatic growth inhibition, mediated by non-lymphocyte effective cells, including monocytes/ macrophages, neutrophils and antiangiogenic chemokines/cytokines (Itoh et al., 1986). As a result, these effective molecules could be expressed by $H S V$ in productively infected cells both in vitro and in vivo. HSV, expressing genes IL-4 and/or IL-10, has shown an ability to infect and destroy glioma cells in vitro (Andreansky et al., 1998). Similarly, intra-cerebral inoculation of $\mathrm{HSV}$, expressing either IL-4 or IL-10 into syngeneic mouse glioma GL-261 cells, implanted in the brains of immune-competent C57BL/6 mice, have been found to produce dramatically opposite physiologic responses. It has also been shown that IL-4-HSV significantly prolonged survival of tumor bearers, whereas tumor-bearing mice, receiving the IL-10-HSV, have had a median survival, identical to that of saline treated controls (Andreansky et al., 1998; Hassan et al., 2000; Liu et al., 
2005). These studies could have direct bearing on the design of vaccine clinical trials for infectious agents and/or malignancy-associated antigens, in which Tlymphocyte co-stimulatory molecules would be employed to enhance antigen-specific T-cell responses.

In examination of the clinical and environmental safety and immunogenicity in the first clinical trial of a live recombinant vaccinia virus, expressing proteins $\mathrm{E} 6$ and E7 of types 16 and 18 of human papilloma virus (HPV), in each patient has been found an anti-vaccinia virus antibody response and three of the eight patients have developed an HPV-specific antibody response (Adams et al., 2001). In one of three available patients, HPV-specific CTLs have also been detected. As highly effective method, with no significant toxicity in mice, gene therapy strategies for treatment of malignant disorders by using of recombinant adenoviral vectors, containing gene $I L-12$, have been characterized (Cordier et al., 1995; Tozola et al., 1997). In vaccination with synthetic RAS peptide, representing mutation $k$-ras in their malignant diseases, a transient ras-specific T-lymphocyte response has been induced (Kung et al., 2000). These results have indicated that specific T-cell responses against uniquely harbored mutations in malignant cells could be induced in cancer patients by vaccination. In this way, recombinant adenoviral gene constructs, encoding malignant antigens, have been proven as useful vaccines, inducing specific T-lymphocyte immunity for therapy of malignant disorders (Cordier et al., 1995; Tozola et al., 1997).

\section{DEVELOPMENT OF NOVEL THERAPEUTIC STRATEGIES WITH LYMPHOCYTES AND THEIR PRECURSORS BY INSERTION OF ADDITIONAL CYTOKINE GENES AND ANTIGENS WITH RECOMBINANT GENE CONSTRUCTS}

Human T-lymphocytes have shown abilities to be efficiently transduced under clinically applicable conditions, by adenoviral gene constructs after 7 days of culture, in the presence of IL-2 and/or IL-7 (Di Nicola et al., 1999; Rosenberg et al., 1998; Zhang et al., 1996). A significant improvement in transduction efficiencies of mouse and human T-lymphocytes by a prolonged preincubation with IL-2 and by the addition of the recombinant adenoviral vector Lipofectamine has also been indicated (Di Nicola et al., 1999). In transfer of chimeric immune receptor genes, ligated into vector pMSCVneo, in human lymphocytes, a mediated antigen-specific nonMHC-restricted cytokine release and malignancy cytotoxicity, as well as inhibition of human xenograft engraftment in experimental mice with severe immunodeficiency, combined with non-obese diabetes (NOD/SCID), has been observed (Douglas et al., 2001). Similarly, a clinically applicable protocol that meets good clinical practice criteria regarding the gene system for transduction and expansion of primary human T-lymphocytes, in which recombinant gene construct, encoding a single chain
FvG250 antibody chimeric receptor (ch-Rec), specific for a RCC-associated antigen (TAA), has been designed in preparation of a clinical phase $1 / 1$ ll study in patients with renal cell carcinoma (RCC) (Douglas et al., 1999; Lamers et al., 2002; Wu et al., 1999; Zhou et al., 2003). According to the results from other studies, evidence of increase of the anti-malignant effect in vivo of lymphocytes, transduced by recombinant herpesviral gene construct HSVtk-DLI, has been provided (Burt et al., 2003). The observed enhanced cytotoxicity of TILs, transduced with recombinant retroviral vector with insertion of gene for TNF, has been ascribed to autocrine effects of this cytokine, which has probably included augmentation of adhesion molecules (CD2 and CD11a) and IL-2 receptor expression, as well as elevation of production of IFNs, lymphotoxin, GM-CSF, as well as their paracrine effects on target cells to facilitate them to be differentiated and genetically-modify lymphocytes (Rosenberg et al., 1990). Treatment with TILs, transduced with retroviral-mediated gene transduction to introduce gene, connected with neomycin resistance, plus addition of cytokine IL-2, has also been proven to mediate the regression of metastatic melanoma (Guenechea et al., 2000; Hass et al., 2000). These data have confirmed the feasibility and safety of strategies, based on recombinant retroviral vectors gene transfer for human gene therapy and have implications for the designing of TILs with improved anti-malignant potency, as well as for the possible use of lymphocytes for the gene therapy of other diseases (Zhang et al., 2004; Zhang et al., 2002).

\section{Conclusion}

DCs and lymphocytes have been characterized as hopeful vehicles for appropriate modulation of the immune response in the presence of appropriate growth factors, cytokines and specific antigens. In this way, they have shown abilities for differentiation in respective directions in the presence of appropriate recombinant viral gene constructs, coding respective antigens, on one hand, and as cell vaccines by gene-engineering manipulations with recombinant vectors, carrying genes for respective malignant antigens or cytokines, on the other. These properties characterize them as promising candidates for construction of novel and safe therapeutic products on their basis, by use of new technologies.

\section{REFERENCES}

Adams N, Borysiewicz L, Fiander A, Man S, Jasani B, Navabi H, Lipetz C, Evans AS, Mason M (2001). Clinical studies of human papilloma vaccines in pre-invasive and invasive cancer. Vaccine 19(1719):2549-2556.

Addison C, Braciak T, Ralston R, Muller WJ, Gauldie J, Graham FL (1995). Intratumoral injection of an adenovirus expressing interleukin2 induces regression and immunity in a murine breast cancer model. Proc. Natl. Acad. Sci. USA 92:8522-8526. 
Aicher A, Westermann J, Cayeux S, Willimsky G, Daemen K, Blankenstein T, Uckert W, Dörken B, Pezzutto A (1997). Successful retroviral mediated transduction of a reporter gene in human dendritic cells: feasibility of therapy with gene-modified antigen presenting cells. Exp. Hematol. 25(1):39-44.

Amirayan AN, Furrie E, Deleuil F, Mellor A, Leserman L, Machy $P$ (1995). Influence of MHC class I molecules on T-cell proliferation induced by CD3 or Thy-1 stimulation. Immunology 86:71-78.

Andreansky SS, He B, van Cott J, McGhee J, Markert JM, Gillespie GY, Roizman BR, Whitley J (1998). Treatment of intracranial gliomas in immunocompetent mice using herpes simplex viruses that express murine interleukins. Gene Ther. 5:2177-2185.

Arthur J, Butterfield L, Roth MD, Bui LA, Kiertscher SM, Lau R, Dubinett S, Glaspy J, McBride WH, Economou JS (1997). A comparison of gene transfer methods in human dendritic cells. Cancer Gene Ther. 4:1023-1028.

Aruga A, Aruga E, Cameron MJ, Chang AE (1997). Different cytokine profiles released by CD4+ and CD8+ tumor-draining lymph node cells involved in mediating tumor regression. J. Leukoc. Biol. 61:507-516.

Avigan D (2004). Dendritic cell-tumor fusion vaccines for renal cell carcinoma. Clin. Cancer Res. 10:6347S-6352S.

Ballas CB, Zielske SP, Gerson SL (2002). Adult bone marrow stem cells for cell and gene therapies: implications for greater use. J. Cell. Biochem. Suppl. 38:20-28.

Banchereau J, Briere F, Caux C, Davoust J, Lebesque S, Liu YJ, Pulendran B, Palucka K (2000). Immunobiology of dendritic cells. Ann. Rev. Immunol. 18:767-811.

Bennett JJ, Malhotra S, Wong RJ, Delman K, Zager J, St-Louis M, Johnson P, Fong $Y$ (2001). Interleukin 12 secretion enhances antitumor efficacy of oncolytic herpes simplex viral therapy for colorectal cancer. Ann. Surg. 233(6):819-826.

Bonini C, Lee SP, Riddell SR, Greenberg PD (2001). Targeting antigen in mature dendritic cells for simultaneous stimulation of CD4+ and CD8+ T-cells. J. Immunol. 166(8):5250-5257.

Borysiewicz LK, Flander A, Numako M, Man S, Wilkinson GW, Westmoreland D, Evans AS, Adams M, Stacey SN, Boursnell ME, Rutherford E, Hickling JK, Inglis SC (1996). A recombinant vaccinia virus encoding human papillomavirus types 16 and 18, E6 and E7 proteins as immunotherapy for cervical cancer. Lancet 347:15231527.

Bovia F, Salmon P, Matthes T, Kvell K, Nguyen TH, Verner-Favre C, Barnet M, Nagy M, Leuba F, Arrighi JF, Piguet V, Trono D, Zibler RH (2003). Efficient transduction of primary human B-lymphocytes and nondividing myeloma B-cells with HIV-1-derived lentiviral vectors. Blood 101(5):1727-1733.

Bradford GB, Williams B, Rossi R, Bertoncello I (1997). Quiescence, cycling, and turnover in the primitive hematopoietic stem cell compartment. Exp. Hematol. 25:445-453.

Bradley JA, Bolton EM, Pedersen RA (2002). Stem cell medicine encounters the immune system. Nat. Rev. Immunol. 2:859-871.

Bregenholt S, Ropke M, Skov S, Claesson MH (1996). Ligation of MHC class I molecules on peripheral blood T-lymphocytes induces new phenotypes and functions. J. Immunol. 157:993-999.

Bubenik J (2001). Genetically engineered dendritic cell-based cancer vaccines. Int. J. Oncol. 18(3):475-478.

Burt RK, Drobisky WR, Seregina T, Traynor A, Oyama Y, Keever-Taylor C, StefjaJ, Kuzel TM, Brush M, Rodriques J, Burns W, Tennant L, Link C (2003). Herpes simplex thymidine kinase gene-transduced donor lymphocyte infusions. Exp. Hematol. 31:903-910.

Cao X, Zhang W, Wang J, Zhang M, Huang X, Hamada H, Chen W (1999). Therapy of established tumour with a hybrid cellular vaccine generated by using granulocyte-macrophage colony-stimulating factor genetically modified dendritic cells. Immunology 97(4):616-625.

Caux C, Dezutter-Dambuyant S, Schmitt D, Banchereau J (1992). GMCSF and TNF- $\alpha$ cooperate in the generation of dendritic Langherans cells. Nature 360:258-261.

Chen L, Chen D, Block E, O'Donnell M, Kufe DW, Clinton SK (1997). Eradication of murine bladder carcinoma by intratumor injection of a bicistronic adenoviral vector carrying cDNAs for the IL-12 heterodimer and its inhibition by the IL-12 p40 subunit homodimer. J. Immunol. 159:351-359.

Cheng L, Du C, Lavau C, Chen S, Tong J, Chen BP, Scollay R, Hawley
RG, Hill B (1998). Sustained gene expression in retrovirally transduced, engrafting human hematopoietic stem cells and their lympho-myeloid progeny. Blood 92(1):83-92.

Cheung N-KV, Guo H-F, Modak S, Cheung IY (2003). Anti-idiotypic antibody facilitates scFv chimeric immune receptor gene transduction and clonal expansion of human lymphocytes for tumor therapy. Hybrid. Hybridomics 22:209-218.

Chun S, Daheshia M, Lee S, Rouse BT (1999). Immune modulation by IL-10 gene transfer via viral vector and plasmid DNA: implication for gene therapy. Cell. Immunol. 194:194-204.

Clark EA, Grabstein KH, Shu GL (1992). Cultured human follicular dendritic cells. Growth characteristics and interactions with Blymphocytes. J. Immunol. 148(11):3327-3335.

Coates PTH, Krishnan R, Kireta S, Johnston J, Russ GR (2001). Human myeloid dendritic cells transduced with an adenoviral interleukin-10 gene construct inhibit human skin graft rejection in humanized NOD-scid chimeric mice. Gene Ther. 8(16):1224-1233.

Cordier L, Duffour M, Sabourin J, Lee MG, Cabannes J, Ragot T, Perricaudet M, Haddada $\mathrm{H}$ (1995). Complete recovery of mice from a pre-established tumor by direct intratumoral delivery of an adenovirus vector harboring the murine IL-12 gene. Gene Ther. 2:16-21.

Curti A, Fogli M, Ratta M, Biasco G, Tura S, Lemoli RM (2001). Dendritic cell differentiation from hematopoietic CD34+ progenitor cells. J. Biol. Regul. Homeostat. Agents 15:49-52.

Dallas MH, Varnum-Finney B, Martin PJ, Bernstein ID (2007). Enhanced T-cell reconstitution by hematopoietic progenitors expanded ex vivo-using the Notch ligand Delta1. Blood 109:35793587.

Davis NL, Brown KW, Johnson RE (1996). A viral vaccine vector that expresses foreign genes in lymph nodes and protects against mucosal challenge. J. Virol. 70:3781-3787.

Dietz AB, Vuk-Pavlović S (1998). High efficiency adenovirus-mediated gene transfer to human dendritic cells. Blood 91(2):392-398.

Djouad F, Bouffi C, Ghannam S, Noël D, Jorgensen C (2009). Mesenchymal stem cells: innovative therapeutic tools for rheumatic diseases. Nat. Rev. Rheumatol. 5:392-399.

Douglas J, Kelly P, Evans JT, Garcia JV (1999). Efficient transduction of human lymphocytes and CD34+ cells via human immunodeficiency virus-based gene transfer vectors. Hum. Gene Ther. 10(6):935-945.

Douglas JL, Lin WY, Panis ML, Veres G (2001). Efficient human immunodeficiency virus-based vector transduction of unstimulated human mobilized peripheral blood CD34+ cells in the SCID-hu Thy/Liv model of human T-cell lymphopoiesis. Hum. Gene Ther. 12(4):401-413.

Di Nicola M, Milanesi M, Magni M, Bregni M, Carlo-Stella C, Longoni P, Tomanin R, Ravagnani F, Scarpa M, Jordan C, Gianni AM (1999). Recombinant adenoviral vector lipofectAMINE complex for gene transduction into human T-lymphocytes. Hum. Gene Ther. 10:18751884.

Domi A, Moss B (1995). Engineering of a vaccinia virus bacterial artificial chromosome in Escherichia coli by bacteriophage $\lambda$-based recombination. Nat. Meth. 2:95-97.

Douglas J, Kelly P, Evans JT, Garcia JV (1999). Efficient transduction of human lymphocytes and CD34+ cells via human immunodeficiency virus-based gene transfer vectors. Hum. Gene Ther. 10:935-945.

Douglas JL, Lin WY, Panis ML, Veres G (2001). Efficient human immunodeficiency virus-based vector transduction of unstimulated human mobilized peripheral blood CD34+ cells in the SCID-hu Thy/Liv model of human T-cell lymphopoiesis. Hum. Gene Ther. 12:401-413.

Engelmayer J, Larsson M, Lee A, Lee M, Cox W, Steinman R, Bhardwaj $N$ (2001). Mature dendritic cells infected with canarypox virus elicit strong anti-human immunodeficiency virus CD8+ and CD4+ T-cell responses from chronically infected individuals. J. Virol. 75(5):21422153.

Eo S, Gierynska M, Kamar A, Rouse B (2001). Prime-boost immunization with DNA vaccine: mucosal route of administration changes the rules. J. Immunol. 166(91):5473-5479.

Fong L, Engelman EG (2000). Dendritic cells in cancer immunotherapy. Ann. Rev. Immunol. 18:245-273.

Frasca L, Fedele G, Deaglio S, Capuano C, Palazzo R, Vaisitti T, Malavasi F, Ausiello CM (2006). CD38 orchestrates migration, 
survival, and Th1 immune response of human mature dendritic cells. Blood 107(6):2392-2399.

Gambotto A, Tuting T, McVey D, Kovesdi I, Tahara H, Lotze MT, Robbins PD (1999). Induction of antitumor immunity by direct intratumoral injection of a recombinant adenovirus vector expressing interleukine-12. Cancer Gene Ther. 6:45-53.

Glymche LH, Murphy KM (2000). Lineage commitment in the immune system: the T-helper lymphocyte grows up. Genes Dev. 14:16931711

Gong J, Chen D, Kashiwaba M, Kufe D (1997). Induction of antitumor activity by immunization with fusions of dendritic and carcinoma cells. Natl. Med. 3(5):558-561.

Gong J, Chen L, Chen D, Kashiwaba M, Manome Y, Tanaka T, Kufe D (1997). Induction of antigen-specific antitumor immunity with adenovirus-transduced dendritic cells. Gene Ther. 4:1023-1028.

Gong J, Nikrui N, Chen D, Koido S, Wu Z, Tanaka Y, Cannistra S, Avigan D, Kufe D (2000). Fusions of human ovarian carcinoma cells with autologous or allogeneic dendritic cells induce antitumor immunity. J. Immunol. 165:1705-1711.

Gong J, Koido S, Chen D, Tanaka Y, Huang L, Avigan D, Anderson K, Ohno T, Kufe D (2002). Immunization against murine multiple myeloma with fusions of dendritic and plasmacytoma cells is potentiated by interleukin-12. Blood 99(7): pp. 2512-2517.

Gray-Parkin K, Stephan RP, Apilado RG, Lill-Elghanian DA, Lee KP, Saha B, Witte PL (2002). Expression of CD28 by bone marrow stromal cells and its involvement in B-lymphopoiesis. J. Immunol. 169:2292-2302.

Green DR, Bissonnette RP, Glynn JM, Shi Y (1992). Activation-induced apoptosis in lymphoid systems. Semin. Immunol. 4:379-388.

Grosenbach DW, Barrientos JC, Scholm J, Hodge JW (2001). Synergy of vaccine strategies to amplify antigen-specific immune responses and antitumor effects. Cancer Res. 61:4497-4505.

Guenechea G, Gan OI, Inamitsu T, Dorrell C, Pereira DS, Kelly M, Naldini L, Dick JE (2000). Transduction of human CD34+ CD38bone marrow and cord blood-derived SCID-repopulating cells with third-generation lentiviral vectors. Mol. Ther. 1(6):566-573.

Hass R, Otte A (2012). Mesenchimal stem cells as all-round supporters in a normal and neoplastic microenvironment. Cell Commun. Signal 10:26.

Hassan W, Sanford MA, Woo SL, Chen SH, Hall SJ (2000). Prospects for herpes-simplex-virus thymidine-kinase and cytokine gene transduction as immunomodulatory gene therapy for prostate cancer. World J. Urol. 18(2):130-135.

Hiraoka K, Yamamoto S, Otsuru S, Nakai S, Tamai K, Morishita R, Ogihara T, Kaneda Y (2004). Enhanced tumor-specific long-term immunity of hemaggluttinating virus of Japan-mediated dendritic celltumor fused cell vaccination by coadministration with $\mathrm{CpG}$ oligodeoxynucleotides. J. Immunol. 173:4297-4307.

Hodge JW, McLaughlin JP, Kantor JA, Schlom J (1997). Diversified prime and boost protocols using recombinant vaccinia virus and recombinant non-replicating avian pox virus to enhance T-cell immunity and antitumor responses. Vaccine 15(6-7):759-768.

Ikuta K, Kina T, MacNeil I, Uchida N, Peault B, Chien YH, Weissman IL (1990). A developmental switch in thymic lymphocyte maturation potential occurs at the level of hematopoietic stem cells. Cell 62:863874.

Inaba K, Inaba M, Romani N, Aya H, Deguchi M, Ikehara S, Muramatsu S, Steinman RM (1992). Generation of large numbers of dendritic cells from mouse bone marrow cultures supplemented with granulocyte/macrophage colonystimulating factor. J. Exp. Med. 176:1693-1702.

Itoh Y, Koshita Y, Takahashi M, Watanabe N, Kohgo Y, Niitsu Y (1995). Characterization of tumor-necrosis-factor-gene-transduced tumorinfiltrating lymphocytes from ascitic fluid of cancer patients: analysis of cytolytic activity, growth rate, adhesion molecule expression and cytokine production. Cancer Immunol. Immunother. 40:95-102.

Itoh K, Tilden A, Balch C (1986). Interleukin-2 activation of cytotoxoic Tlymphocytes infiltration into human metastatic melanoma. Cancer Res. 46:3011-3017.

Jackson DG, Bell JI (1990). Isolation of a cDNA encoding the human CD38 (T10) molecule, a cell surface glycoprotein with an unusual discontinuous pattern of expression during lymphocyte differentiation.
J. Immunol 144:2811-2815.

Kang SK, Shin S, Ko MS, Jo JY, Ra JC (2012). Journey of mesenchymal stem cells for homing: strategies to enchance efficacy and safety of stem cell therapy. Stem Cell Int. 2012:342968.

Kao JY, Gong Y, Chen CM, Zheng QD, Chen JJ (2003). Tumor-derived TGF- $\beta$ reduces the efficacy of dendritic cell/tumor fusion vaccine. J. Immunol. 170:3806-3811.

Kaplan J, Yu Q, Piraino S, Pennington SE, Shankara S, Woodworth LA, Roberts BL (1999). Induction of antitumor immunity with dendritic cells transduced with adenovirus vector-encoding endogenous tumorassociated antigens. J. Immunol. 163:699-707.

Kauffman E, Bublot M, Gettig R, Limbash K, Pincus S, Taylor J (2001). Live viral vectors. In: New vaccine technologies, Ronald WE (ed.) BioChem Pharma, Inc. Northborough, Massachusetts, USA. P 303.

Kent SJ, Zhao A, Best SJ, Chandler JD, Boyle DB, Ramshaw IA (1998). Enchanced T-cell immunogenicity and protective efficacy of a Human Immunodeficiency Virus Type I vaccine regimen consisting of consecutive priming with DNA and boosting with recombinant fowlpox virus. J. Virol. 72:10180-10188.

Kim HS, Zhang X, Choi YS (1994). Activation and proliferation of follicular dendritic cell-like cells by activated T-lymphocytes. J. Immunol. 153(7):2951-2961.

Kobari L, Pflumio F, Giarratana M, Li X, Titeux M, Izac B, Leteurtre F, Coulombel L, Douay $L(2000)$. In vitro- and in vivo-evidence for the long-term multilineage (myeloid, B-, NK, and T-) reconstitution capacity of ex vivo-expanded human CD34(+) cord blood cells. Exp. Hematol. 28:1470-1480.

Kobari L, Giarratana MC, Pflumio F, Izac B, Coulombel L, Douay L (2001). CD133+ cell selection is an alternative to CD34+ cell selection for ex vivo-expansion of hematopoietic stem cells. J. Hematother. Stem Cell Res. 10:273-281.

Koido S, Hara E, Homma S, Mitsunaga M, Takahara A, Nagasaki E, Kawahara H, Watanabe M, Toyama Y, Yanagisawa S, Kobayashi S, Yanaga K, Fujise K, Gong J, Tajiri H (2007). Synergistic induction of antigen-specific CTL by fusions of TLR-stimulated dendritic cells and heat-stressed tumor cells. J. Immunol. 179:4874-4883.

Kondo M, Weissman IL, Akashi K (1997). Identification of clonogenic common lymphoid progenitors in mouse bone marrow. Cell 91:661672.

Kung SK, An DS, Chen IS (2000). A murine leukemia virus (MuLV) long terminal repeat derived from rhesus macaques in the context of a lentivirus vector and MuLV gag sequence results in high-level gene expression in human T-lymphocytes. J. Virol. 74:3668-3681.

Lai AY, Kondo M (2007). Identification of a bone marrow precursor of the earliest thymocytes in adult mouse. Proc. Natl. Acad. Sci. U. S. A. 104: 6311-6316.

Lamers CHJ, Willemsen RA, Luider BA, Debets R, Bolhuis RLH (2002). Protocol for gene transduction and expansion of human $\mathrm{T}$. lymphocytes for clinical immunogene therapy of cancer. Cancer Gene. Ther. 9:613-623.

Lazarus HM, Koc ON, Devine SM, Curtin P, Maziarz RT, Holland HK, Shpall EJ, McCarthy P, Atkinson K, Cooper BW, Gerson SL, Laughlin MJ, Loberiza FR, Moseley AB, Bacigalupo A (2005). Cotransplantation of HLA-identical sibling culture-expanded mesenchymal stem cells and hematopoietic stem cells in hematologic malignancy patients. Biol. Blood Marrow Transplant. 11:389-398.

Lehtonen A, Ahlfors $\mathrm{H}$, Veckman V, Miettinen $M$, Lahesmaa $R$, Julkunen I (2007). Gene expression profilling during differentiation of human monocytes to macrophages or dendritic cells. J. Leukoc. Biol. 82(3):710-720

Liu Y (2003). Engineered fusion hybrid vaccine of IL-4 gene-modified myeloma and relative mature dendritic cells enhances antitumor immunity. Leukoc. Res. 26(8):757.

Liu R, Varghese S, Rabkin SD (2005). Oncolytic herpes simplex virus vector therapy of breast cancer in C3(1)/SV40 T-antigen transgenic mice. Cancer Res. 65(4):1532-1540.

Lu L, Lee W-C, Gambotto A, Zhong C, Robbins PD, Qian S, Fung JJ, Thomson AW (1998). Transduction of dendritic cells with adenoviral vectors encoding CTLA4-lg markedly reduces their allostimulatory ability. Transplantation 65:106-109.

Maitra B, Szekely E, Gjini K, Laughlin MJ, Dennis J, Haynesworth SE, Koc ON (2004). Human mesenchymal stem cells support unrelated 
donor hematopoietic stem cells and suppress T-cell activation. Bone Marrow Transplant. 33:597-604.

Mandl S, Sigal LJ, Rock KL, Andino R (1998). Poliovirus vaccine vectors elicit antigen-specific cytotoxic $\mathrm{T}$-cells and protect mice against lethal challenge with malignant melanoma cells expressing a model antigen. Proc. Natl. Acad. Sci. U. S. A. 95:8216-8221.

Martinet W, Saelens X, Deroo T, Neirynck S, Contreras R, Min Jou W, Fiers W (1997). Protection of mice against a lethal influenza challenge by immunization with yeast-derived recombinant influenza neuraminidase. Eur. J. Biochem. 247:332-338.

Mitchell TC, Haldeman D, Kedl RM, Teague TK, Schaefer BC, White J, Zhu Y, Keppler J, Marrack P (2001). Immunological adjuvants promote activated T-cell survival via induction of $\mathrm{Bcl}-3$. Nat. Immunol. 2:397-402.

Overwijk WW, Lee DS, Surman DR, Irvine KR, Touloukian CE, Chan CC, Carroll MW, Moss B, Rosenberg SA, Restifo NP (1999). Vaccination with a recombinant vaccinia virus encoding a"self" antigen induces autoimmune vitiligo and tumor cell destruction in mice: requirement for CD4+ T-lymphocytes. Proc. Natl. Acad. Sci. U. S. A. $96: 2982-2987$.

Palese P, Roizman B (1996). Genetic engineering of viruses and of virus vectors: a preface. Proc. Natl. Acad. Sci. U. S. A. 93: p. 11287.

Panicali D, Paoletti E (1982). Construction of poxviruses as cloning vectors: insertion of the thymidine kinase gene from herpes simplex virus into the DNA of infectious vaccinia virus. Proc. Natl. Acad. Sci. U. S. A. 79:4927-4931.

Parkhurst MR, De Pan C, Riley JP, Rosenberg SA, Shu S (2003). Hybrids of dendritic cells and tumor cells generated by electrofusion simultaneously present immunodominant epitopes from multiple human tumor-associated antigens in the context of MHC class I and class II molecules. J. Immunol. 170:5317-5325.

Ra JC, Kang SK, Shin S, Park HG, Joo SA, Kim JG, Kang B-C, Lee SY, Nakama K, Piao M, Sohl B, Kurtz A (2011): Stem cell treatment for patients with autoimmune disease by systematic infusion of cultureexpanded autologous adipose tissue derived mesenchymal stem cells. J. Transl. Med. 9:181.

Reid CDL, Stackpole A, Meager A, Tikepae J (1992). Interaction of tumor necrosis factor with granulocyte-macrophage colonystimulating factor and other cytokines in the regulation of dendritic cell growth in vitro from bipotent CD34+ progenitors in human bone marrow. J. Immunol. 149:2681-2688.

Ribas A, Butterfield L, McBride W, Jilani SM, Bui LA, Vollmer CM, Lau R, Dissette VB, Hu B, Chen AY, Glaspy JA, Economou JS (1997). Genetic immunization for the melanoma antigen MART-1/melan-A using recombinant adenovirus-transduced murine dendritic cells. Cancer Res. 57:2865-2869.

Rosenberg S (1996). The immunotherapy of solid cancers based on cloning the genes encoding tumor-rejection antigens. Ann. Rev. Med. 47:481-491.

Rosenberg SA, Yannelli JR, Yang JC, Topalian SL, Schwartzentruber DJ, Weber JS, Parkinson DR, Seipp CA, Einhorn JH, White DE (1994). Treatment of patients with metastatic melanoma with altologous tumor-infiltrating lymphocytes and interleukin-2. J. Natl. Cancer Inst. 86:1159-1166.

Rosenberg S, Zhai Y, Yang J, Schwartzentruber DJ, Hwu P, Marincola FM, Topalian SL, Restifo NP, Seipp CA, Einhorn JH, White DE (1998). Immunizing patients with metastatic melanoma using recombinant adenoviruses encoding MART-1 and gp1000 melanoma antigens. J. Natl. Cancer Inst. 90:1894-1900.

Rosenberg SA, Aebersold P, Cornetta K, Kasid A, Morgan RA, Moen R, Karson EM, Lotze MT, Yang JC, Topalian SL, Merino MJ, Culver K, Miller D, Blaese M, Anderson WF (1990). Gene transfer into humans - immunotherapy of patients with advanced melanoma, using tumorinfiltrating lymphocytes modified by retroviral gene transduction. $\mathrm{N}$ Engl. J. Med. 323:570-578.

Sadegah M, Weiss W, Sacci JB (2000). Improving protective immunity induced by DNA-based immunization: priming with antigen and GMCSF encoding plasmid DNA and boosting with antigen expressing recombinant poxvirus. J. Immunol. 164:5905-5912.

Sell S (2004). Stem cell origin of cancer and differentiation therapy. Crit. Rev. Oncol. Hematol. 51:1-28.

Siders W, Wright P, Hixon J, Alvord WG, Back TC, Wiltrout RH, Fenton
RG (1998). T-cell and NK cell independent inhibition of hepatic metastases by systemic administration of IL-12-expressing recombinant adenovirus. J. Immunol. 160:5465-5474.

Siena S, Di Nicola M, Bregni M, Mortarini R, Anichini A, Lombardi L, Ravagnani F, Parmiani G, Gianni AM (1995). Massive ex vivogeneration of functional dendritic cells from mobilized CD34+ blood progenitors for anticancer therapy. Exp. Hematol. 23:1463-1471.

Suzuki T, Fukuhara T, Tanaka M, Nakamura A, Akiyama K, Sakakibara T, Koinuma D, Kikuchi T, Tazawa R, Maemondo M, Hagiwara K, Saijo Y, Nukiwa T (2005). Vaccination of dendritic cells loaded with interleukin-12-secreting cancer cells augments in vivo-antitumor immunity: characteristics of syngeneic and allogeneic antigenpresenting cell cancer hybrid cells. Clin. Cancer Res. 11:58-66.

Terskikh AV, Bryant PJ, Schwartz PH (2006). Mammalian stem cells. Pediatric Res. 59:13R-20R.

Tozola E, Hunt K, Swisher S (1997). In vivo-cancer gene therapy with a recombinant interleukin-2 adenovirus vector. Cancer Gene Ther. 4:17-25.

Tsang KY, Zaremba S, Nieroda CA, Zhu MZ, Hamilton JM, Schlom J (1995). Generation of human cytotoxicic T-cells specific for human carcinoembryonic antigen epitopes from patients immunized with recombinant vaccinia-CEA vaccine. J. Natl. Cancer Inst. 87:982-990.

Vasiri B, Wu Z, Crawford K, Rosenblatt J, Zarwan C, Bissonnette A, Kufe D, Avigan D (2008). Fusions of dendritic cells with breast carcinoma stimulate the expansion of regulatory T-cells while concomitant exposure to IL-12, CpG oligodeoxynucleotides, and antiCD3/CD28 promotes the expansion of activated tumor reactive cells. J. Immunol. 181:808-821.

Vogelstein B, Kinzler KW (2004). Cancer genes and pathways they control. Nat. Med. 10:789-799.

Walden P (2000). Hybrid cell vaccination for cancer immunotherapy. Adv. Exp. Med. Biol. 465:347-354.

Wang J, Saffold S, Cao X, Krauss J, Chen W (1998). Eliciting T-cell immunity against poorly immunogenic tumors by immunization with dendritic cell-tumor fusion vaccines. J. Immunol. 161:5516-5524.

Wang M, Bronte V, Chen PW, Gritz L, Panicali D, Rosenberg SA, Restifo NP (1995). Active immunotherapy of cancer with a nonreplicating recombinant fowlpox virus encoding a model tumorassociated antigen. J. Immunol. 154:4685-4692.

Wu AG, Liu X, Mazumder A, Bellanti JA, Meehan KR (1999). Improvement of gene transduction efficiency in T-lymphocytes using retroviral vectors. Hum. Gene Ther. 10:977-982.

Wen Ju D, Tao Q, Lou G, Bai M, He L, Yang Y, Cao X (2001). Interleukin-18-transfection enhances antitumor immunity induced by dendritic cell-tumor cell conjugates. Cancer Res. 61:3735-3740.

Wildner O, Morris JC (2000). The role of the E1B $55 \mathrm{kDa}$ gene product in oncolytic adenoviral vectors expressing herpes simplex virus-tk: assessment of antitumor efficacy and toxicity. Cancer Res. 60(15):4167-4174.

Xia D, Li F, Xiang J (2004). Engineered fusion hybrid vaccine of $I L-18$ gene-modified tumor cells and dendritic cells induces enhanced antitumor immunity. Cancer Biother. Radiopharm. 19(3):322-330.

Xia D, Chan T, Xiang J (2005). Dendritic cell/myeloma hybrid vaccine. Meth. Mol. Med. 113: 225-234

Xia J, Tanaka Y, Koido S, Liu C, Mukherjee P, Gendler SJ, Gong J (2003). Prevention of spontaneous breast carcinoma by prophylactic vaccination with dendritic/tumor fusion cells. J. Immunol. 170:19801986.

Yongqing Z, Chan WT, Saxena A, Xiang J (2002). Engineered fusion hybrid vaccine of IL-4 gene-modified myeloma and relative mature dendritic cells enhances antitumor immunity. Leuk. Res. 26(18):757763.

Zhai Y, Yang J, Kawakami Y, Spiess P, Wadsworth SC, Cardoza LM, Couture LA, Smith AE, Rosenberg SA (1996). Antigen-specific tumor vaccines: development and characterization of recombinant adenoviruses encoding MART1 or gp100 for cancer therapy. J. Immunol. 156:700-710.

Zhang J, Hu C, Geng Y, Blatt L, Taylor M (1996). Gene therapy with adeno-associated virus carrying an interferon gene results in tumor growth suppression and regression. Cancer Gene Ther. 3:31-38.

Zhang XY, La Russa VF, Reiser J (2004). Transduction of bone marrow-derived mesenchymal stem cells by using lentivirus vectors 
pseudotyped with modified RD114 envelope glycoproteins. J. Virol. 78:1219-1229.

Zhang XY, La Russa VF, Bao L, Kolls J, Schwarzenberger P, Reiser J (2002). Lentiviral vectors for sustained transgene expression in human bone marrow-derived stromal cells. Mol. Ther. 5:555-565.
Zhou X, Cui Y, Huang X, Yu Z, Thomas AM, Ye Z, Pardoll DM, Jaffee EM, Cheng $L$ (2003). Lentivirus-mediated gene transfer and expression in established human tumor antigen-specific cytotoxic T-cells and primary unstimulated T-cells. Hum. Gene Ther. 14:1089-1105. 